Global Journal of Human Resource Management

Vol.8, No.2, pp.33-57, June 2020

Published by ECRTD-UK

Print ISSN: 2053-5686(Print), Online ISSN: 2053-5694(Online)

\title{
EMPLOYEE TRAINING ON CUSTOMER SATISFACTION: MEDIATING ROLE OF EMPLOYEE PERFORMANCE AND THE MODERATING ROLE OF JOB AUTONOMY
}

\author{
Muhammad Hammad Shah \\ Employee Housing Foundation Progressive (EHFPRO Pvt. Ltd) \\ Islamabad Pakistan \\ Muhammad Waseem Shah \\ Employee Housing Foundation Progressive (EHFPRO Pvt. Ltd) \\ Islamabad Pakistan \\ Syeda Fareeha Gul \\ Rehman Medical Institute Peshawar Pakistan
}

\begin{abstract}
This study focused on proposed hypothetical model to explore the association between employee training and customer satisfaction of retail sector in Pakistan, while observing employee performance in mediating role and job autonomy in moderating role. The study was conducted by cross-sectional survey among employees and customers of selected organizations of Rawalpindi and Islamabad cities, respectively. Sample consists of 224 employees and data collection was done by the distribution of structured questionnaires through convenience sampling technique. In statistical analysis to draw conclusions analytical tools such as reliability, correlation, and regression analysis were used. From results it was observed that there was a positive association between employee training and customer satisfaction. Also, the results of the study supported the highly significant mediating role of employee performance on the association between employee training and customer satisfaction. Similarly the results confirmed the moderating role of job autonomy between employee training and customer satisfaction. So it is well concluded that retail companies should introduce training of employees which will enhance their performance and will help them deliver a better customer service and definitely customers will be satisfied. Similarly if employees are well trained, so they will act and work autonomously which will boost customer satisfaction.
\end{abstract}

KEYWORDS: employee training, customer satisfaction, retail sector, employee performance, customer service, job autonomy

\section{INTRODUCTION}

Nowadays capital of an organization can be enhanced through training of their employees. The huge assets of organization are not its structure but their employees because their employees can earn success to that organization. Training is defined as an efficient process of getting knowledge, abilities, skills and the behavior to meet the requirements of the job (Gomez-Mejia 2007). Training helps employees to meet their existing job requirements or helps employees to increase their productivity. Training not only develops the capabilities of the employee but sharpen their thinking 
Global Journal of Human Resource Management

Vol.8, No.2, pp.33-57, June 2020

Published by ECRTD-UK

Print ISSN: 2053-5686(Print), Online ISSN: 2053-5694(Online)

ability and creativity in order to take better decision in time and in a more productive manner (David, 2006). Moreover it also enables employees to deal with the customer in an effective manner and respond to their complaints in timely manner (Hollenbeck, Derue and Guzzo, 2004). According to Rowden and Conine (2005), trained employees are more able to satisfy the customers. It is an organizational challenge to integrate training and development in humanresource planning and use training to increase employee's skills and motivation to work towards a common business goal as opposed to considering training as an isolated activity (Macky \& Johnson, 2000). Training is about changing the behavior of the trainee and measuring of training benefits have to start with a consideration of the behavioral change that may or may not have occurred. Therefore the goal of training is for its employees to master the knowledge, skill and behaviors emphasized in training programs and to apply them to their day to day activities (Lashley, 2002). Consumers are demanding more from retailers and are making decisions on where to shop based on their expectations of merchandise quality and customer service. For a retailer to be successful they have to offer excellent customer service while ensuring a competitive pricing of their goods. Today consumers have more choices than ever before and if they do not find what they want at an acceptable and in a friendly environment they will shop elsewhere (Zachman and Folker 2009).

Satisfaction is identified in a variety of senses which depends on what were the customer needs before the service, it narrows down from feelings of fulfillment, pleasure, happiness, enjoyment and relief (Zoe, 2006). Customer evaluates the service from the quality of service they are served with (Lam and Borton 2006). According to Zeithamal et al. (2006) the customer satisfaction is when the service the customers are being served with, matches the customer expectation.

If customers are satisfied and are well served then the success will be for the business. Customer satisfaction can be achieved through its employees. The employees who are dealing with customers shall be well trained. If employees are well trained their performance will ameliorate and definitely customers will be satisfied. Improved capabilities, knowledge and skills of the talented workforce are among some of the main sources of competitive advantage in a global market (McKinsey, 2006). To develop the desired knowledge, skills and abilities of the employees, to perform well on the job, requires effective training programs which definitely effect employee motivation and commitment (Meyer and Allen, 1991). Nowadays organizations apply long term planning and invest in building new skills for their workers, which helps them to cope with the uncertain conditions that they may face in future, thus, improves the performance of employees through superior level of motivation and commitment. When employees recognize their organization interest in them through offering training programs, they in turn apply their best efforts to achieve organizational goals, and show high performance on job. Training is a necessity in the workplace (Ingersoll, 2005). Without training, employees don't have a command on their responsibilities or duties (Warner, 2005). Employee training refers to programs that provide workers with information, new skills, or professional development opportunities

Training develops efficiency and results in superior performance on job (Svenja, 2007), by replacing the traditional weak practices by efficient and effective job related practices (Kathiravan, Devadason and Zakkeer, 2006). Training refers to a planned intervention which aims to improve 
Global Journal of Human Resource Management

Vol.8, No.2, pp.33-57, June 2020

Published by ECRTD-UK

Print ISSN: 2053-5686(Print), Online ISSN: 2053-5694(Online)

the elements of employee job performance (Chiaburu and Tekleab, 2005). It is all about improving the competency and expertise that seems to be necessary for the achievement of organizational goals and objectives. Training programs may also help the employees to lessen their anxiety or frustration, which are originated by the work on job (Chen et al., 2004).

Training is determined as the process of enabling employee to complete the task with greater efficiency and is a vital element of managing the human resource performance strategically (Lawler, 1993; Delaney and Huselid, 1996). If employees are given training programs on their roles, so their performance will enhance and the customers will be satisfied. The customers will then stick to that organization and profit will be for the organization. Employee performance, achieved through training, refers to immediate improvements in the knowledge, skills and abilities to carry out job related work, and hence achieve more employee commitment towards the organizational goals (Huselid, 1995; Ichniowski et al., 1997). Kamoche and Mueller (1998) mentioned that training leads to increase in learning capabilities and enhances employee performance and ultimately higher return on investment (in training) for the firm. According to Wright and Geroy (2001), employee skills and behaviors change through effective training programs. It not only improves the overall performance of individuals but also improves the knowledge, skills of the workers which are necessary for the future job. Through training the employee competencies are developed which enables them to implement the job related work efficiently, and achieve objectives of organizations in a timely and in competitive manner.

Job autonomy refers to the way of acting independent while performing on job (Baard \& Deci, 2004). Job autonomy means the freedom and independence with which the employees work in his organization (Hackman and Oldham, 1976). The employees work independently when they know how to deal with customers, how to fulfill their needs in a timely manner and how to satisfy them. So what if customer needs are not fulfilled in a timely manner? The result may be that the business will lost its name in the market and the business cannot compete with its rivalries and ultimately will fail. The need for autonomy is marked as one of the principal needs which helps employee to perform well on their jobs (Sheldon, Elliot, Kim, \& Kasser, 2001).If employees are well trained they will develop skills like how to deal with customers, how to satisfy their needs in timely manner and satisfy them and their work autonomy will enhance and definitely the customers will be satisfied. Employees who have high job autonomy feel responsibility for their work outcomes since their personal initiative and perception on how to do the job can effect work outcomes in a direct manner (Bandura, 1999; Hackman and Oldham, 1976). Thus the employees with high job autonomy will fulfill the needs of customers accurately and in a timely manner because the employee will know everything about the job environment and products they are selling. For example: If the employees are well trained and they are given all sorts of information regarding every product they are selling and if a customer needs some specific information regarding a product. So employee without asking anyone can give the customer information and can satisfy his needs in a remarkable and timely manner. Employees with low job autonomy have less freedom, discretion and less power to attain customer satisfaction (Parker \& Wall, 2001). 
Global Journal of Human Resource Management

Vol.8, No.2, pp.33-57, June 2020

Published by ECRTD-UK

Print ISSN: 2053-5686(Print), Online ISSN: 2053-5694(Online)

\section{Problem Statement}

This study focuses on retail sector in Pakistan as in many multinational companies it is a big problem that whenever they hire new employees they could not satisfy the customers and ultimately their productivity is low. The reason for this problem is that employees are not trained on their job positions due to which their performance is low and customers are not satisfied from the way they serve them. Although the business main goal is to retain its customers and to serve them in an efficient and timely manner, but this cannot be achieved without training of its employees. Similarly the second main problem in retail sector is that employees are not well trained due to which they cannot work with freedom to deal with customers and fulfill their needs and achieve the business objectives. The pros of this study will be that customer satisfaction will enhance by giving the employees training as this training will help to enhance job autonomy of employees due to which employee will act independently. Similarly this study will help to enhance performance of employees by giving them training which will ultimately result in enhanced customer satisfaction. If this study is not done the cons will be that employees of targeted industry will still face such problem which will result in dissatisfaction of customers and ultimately business will result in failure.

\section{Research Objectives:}

The objectives of the study are as follows:

- To understand the importance of training in retail sector

- To discover the aggregate work of employee training, job autonomy, employee performance and customer satisfaction in retail sectors of Pakistan

- To analyze the impact of employee training on customer satisfaction

- To analyze the impact of employee performance on customer satisfaction

- $\quad$ To find out the mediating role of employee performance between employee training and customer satisfaction.

- To find out the moderating role of Job autonomy between employee training and customer satisfaction

\section{Research Questions:}

- What is the impact of employee training on customer satisfaction?

- What is the impact of employee training on employee performance?

- What is the impact of employee performance on customer satisfaction?

- Does employee performance mediate between employee training and customer satisfaction?

- $\quad$ Does job autonomy moderates between employee training and customer satisfaction?

\section{Research Significance:}

Nowadays the productivity and profit depends upon the customers. In-fact the business main goal is to retain its customers and to achieve their satisfaction. But retaining the customers and to achieve their satisfaction is a challenge in retail sector. Hence this study will cover as how to satisfy the customer and to achieve business goals and objectives. The significance of this study would be that it would greatly ameliorate the productivity for the organizations. Training of employees 
Global Journal of Human Resource Management

Vol.8, No.2, pp.33-57, June 2020

Published by ECRTD-UK

Print ISSN: 2053-5686(Print), Online ISSN: 2053-5694(Online)

would result in an outclass performance of employees which ultimately will result in customer satisfaction and will enhance the revenue of organizations. Secondly this study will help out the managers and owners of the organizations to better understand the importance of training and to initiate the training programs in their organizations so in order to attain the customer satisfaction.

\section{LITERATURE REVIEW}

\section{Employee Training and Customer Satisfaction:}

Chaichi (2012) studied the impact of staff training on customer satisfaction in travel agencies in Malaysia. A sample size of 167 customers who travelled with travel agencies was utilized for carrying out the study. The results showed that if the staff of travel agency will be trained well so the customers will be satisfied. Some of the employees have lack of skills, abilities, knowledge and competencies due to this they are failed to accomplish task on timely basis and customers are not satisfied (Zuhair Abbas 2014). Agarwal (2010) stated that development of skills of employees and to satisfy the customers are the main purposes of training of employees. Training helps managers to gain knowledge, skills, abilities and competencies which are used to solve challenges experienced at workplace and at the same time to help employees realize their career goals and aspirations i.e. customer satisfaction (Blanchard, 2004). Training gives learning opportunities and leads to organizational commitment and customer satisfaction (Armstong, 2009). According to a study by Choo and Bowley (2007) stated that training has a positive impact on productivity which results in customer satisfaction and thus enhancing the brand value. Michael and Combs (2008) while conducting their study deduced that training lessens the chance of failure as training ameliorate performance and enhances satisfaction. Therefore, the main requirement for companies is to implement practices and activities that can support employees to get better and perform well in their positions in order to achieve organizational goals (Mathis et al., 2014). Therefore, in response to an increasingly competitive marketplace, growing research attention is being devoted to factors that contribute to desired consumer satisfaction (Liao and Chuang 2004). Some researchers argue that employee training has more positive effect on CS rather than other human resource practices (Cantarello et al., 2012). Cantarello et al. (2012) carried out his study to find out that which human resource practices are beneficial for the success of organization. The results showed that training is the most important practice of human resource which enhances the employee skills and abilities and make the customers satisfy by giving them outclass service.

Lee (2012) stated that training is seen as an important driver of a customer service and as an extension of a desirable outcome like customer satisfaction. And as the main objective of any organization is to achieve the customer satisfaction, many companies have created customer service training programs, due to which employees abilities and skills are enhanced and serve the customers with a best service. Kumari et al. (2013) stated that in current competitive business environment, customer happiness is the main target of organizations. That's why companies are trying to give the customers a better service in order to satisfy their consumers. Organizations are trying to provide excellent services and products in a timely matter in order to be competitive in the market. 
Global Journal of Human Resource Management

Vol.8, No.2, pp.33-57, June 2020

Published by ECRTD-UK

Print ISSN: 2053-5686(Print), Online ISSN: 2053-5694(Online)

Employee training makes a huge contribution to customer satisfaction, as high performing workforce and better qualified, can meet the demands of consumers (Putachote, 2013). Feng et al. (2014) conducted a study on the effects of employee training and empowerment on customer satisfaction. The sample size included 214 Chinese manufacturing companies. By using structural equation modelling it was deduced that employee training and empowerment has positive impact on employee training. Hence our proposed hypothesis is:

\section{H1: Employee training has a positive impact on customer satisfaction}

\section{Employee training and Employee Performance:}

Training has been shown as performance improvement related benefits for the employee as well as for the organization by effecting performance of employees positively which help in the development of employee knowledge, skills, ability, competencies and behavior (Appiah 2010; Harrison 2000; Guest 1997). Swart et al. (2005) concluded from his study that training helps to ameliorate of skills and performance which is a way of improving employee performance. According to Swart et al., (2005) stated that training helps the employees develop skills and competencies in which employees are lacking. Moreover he stated from his study that training helps the employees to enhance their performance and achieve the organizational goals and objectives. According to Wright \& Geroy (2001), the employee abilities and competencies improve mostly through effective training programs. He deduced that training and performance are positively correlated such that training not only enhances performance but also changes the behavior and skills of employees. Training is a function of capacity building in organizations which is used to enhance performance of employees and helps to attain objectives of organizations (Tahir, Yousafzai, Jan, \& Hashim, 2014). Training is the most important among human resource management practices which is planned, systematic and its outcomes help out to enhance skills and knowledge that are important to perform work effectively (Sultana, Irum, Ahmed, \& Mehmood, 2012). According to Sultan et al. (2012), employees who are given training on their job are said to be perform well in contrast to the employees who are not offered training programs. Pfeffer (1994) from his study stated that well-trained employees have more capability of attaining performance targets and gaining competitive advantage and uniqueness in the market. Employee performance enhanced through training programs which refer to improvements and gain in the knowledge, skills and capabilities in order to carry out the job related duty, and achieves more employee commitment towards the organizational goals (Huselid, 1995; Ichniowski et al., 1997). Bartel (1994) deduced from his study that there is a positive relationship between effective training program and employee productivity, however to make it possible, (Swart et al., 2005), it is the responsibility of the managers to identify the factors that blocks training program effectiveness and shall take corrective measures to enhance their effect on employee performance. Kamoche and Mueller (1998) from their study deduced that training mostly leads to ameliorate the learning and knowledge and enhances employee performance and ultimately returns higher on the investments (in training) for the firm. Guest (1997) stated in his research study that training programs are the most important aspect of human resource management practices that has positive impact on the employee knowledge, skills and capabilities which ultimately leads to higher performance of employees. Farooq. M, \& Aslam. M. K (2011) carried out a study to see the impact of training on employee performance. It was concluded from the study that training and employee performance are positively correlated $(r=.233)$. Similarly the study conducted by Sultana. A, et.al. (2012) 
Global Journal of Human Resource Management

Vol.8, No.2, pp.33-57, June 2020

Published by ECRTD-UK

Print ISSN: 2053-5686(Print), Online ISSN: 2053-5694(Online)

carried out in in telecom sector of Pakistan stated that employee training and performance are positively associated with each other. Similarly $\left(\mathrm{R}^{2}=.501\right)$ showed that training is responsible for a variation of $50.1 \%$ in performance of employees. Hence our proposed hypothesis is:

\section{H2: Employee training has a positive impact on employee performance}

\section{Employee Performance and Customer Satisfaction}

Nowadays the main target of companies is the customers. Customer satisfaction is the most important aspect of business success and profit. Customers satisfaction depends upon employee performance i.e. if employees are performing well and they deliver an outclass service so definitely the customers will be satisfied and will retain to that organization. The capability of employees to respond in a timely manner and to satisfy customer needs is an important aspect of competitiveness and of success for many companies (Gursoy and Swanger, 2007). Employee performance has positive effect on customer satisfaction in the service industry (Harter, Schmidt \& Hayes, 2002). Hays and Hill (1999) concluded from their study that it's hard to achieve customer satisfaction in services sector rather than manufacturing which is due to face to face interaction between customer and employee. They stated that employee performance is important aspect of service industry which ultimately results in satisfaction of customers.

As employees are the one who are in direct contact with customers, so if employee performance is low so definitely customers will not be satisfied and they will go elsewhere. Employee performance was closely related to customer reliability, customer satisfaction, productivity, profitability and consumer loyalty, and was negatively correlated with employee turnover (Harter, Schmidt and Hayes, 2002). Research has shown that service quality is ultimately related to customer loyalty and retention and, eventually, to higher profits for the organization (Rust \& Zahorik, 1993; Storbacka, Strandvik, \& Gronroos, 1994). Research has shown that excellent performance is positively related to customer loyalty, in the sense that good performance predicts customer loyalty (Bitner, Booms, \& Tetreault, 1990; Kumar, 2002). Rabbanee et al. (2015) conducted a study on the impact of employee performance on customer loyalty and concluded that employee performance has a positive impact on customer loyalty. Furthermore, he stated that loyalty of customers is achieved if customers are satisfied. So if employees perform well so customers will be satisfied and will become loyal. Schneider and Bowen (1999) from their study stated that customer dissatisfaction and outrage, often results of performance of employees i.e. when employees don't perform well and don't satisfy the needs of customer within the time frame so customers feel dissatisfied.

Choudry. P (2014) studied the impact of employee performance on satisfaction of employees in life insurance corporations in India. The results show that customer satisfaction is dependent on employee performance and employee performance and customer satisfaction are positively correlated $(\mathrm{r}=.681)$. Hence our proposed hypothesis is:

\section{H3: Employee performance has a positive impact on customer satisfaction}

\section{Job autonomy as moderator:}

Job autonomy is defined as the degree of freedom and independence with which an employee works. Job autonomy refers to the experience of free will, or volition, in an action or task (Ryan 
Global Journal of Human Resource Management

Vol.8, No.2, pp.33-57, June 2020

Published by ECRTD-UK

Print ISSN: 2053-5686(Print), Online ISSN: 2053-5694(Online)

\& Deci, 2000; Deci \& Ryan, 1985). Fuller et al. (2010) studied the moderating role of Job autonomy between Proactive personality and Job performance and concluded that job autonomy plays a moderating role between proactive personality and job performance. Past studies argued that autonomy of employee leads to positive behaviors like psychological involvement, selfgovernance, and persistence to organizational goals (Deci and Ryan, 1985; Gagne, 2003). Jafri. H (2018) studied the relation between emotional intelligence and employee creativity and used job autonomy as moderator. A sample size of 233 employees was selected from two financial sectors. The moderated regression analysis showed that job autonomy strengthened the association between emotional intelligence and creativity. Employee tendency to take decisions by themselves makes the employees enthusiastic about the goals and objectives of company (Stewart et al., 2011). Goussinsky. R (2015) studied the moderating role of job autonomy among customer aggression, felt anger and emotional deviance. From the results it was concluded that under conditions of periodic exposure to customer aggression, high level of job autonomy was correlated with high frequent instances of emotional deviance. Similarly correlation between anger and emotional deviance was higher for employees reporting high levels of job autonomy.

Li. M, Yi-Han, W.L and Zhang (2015) studied autonomy orientation and thriving at work on the relationship between empowering leadership and change-oriented organizational citizenship behavior and concluded that autonomy orientation positively moderates the relationship between empowering leadership and change-oriented organizational citizenship behavior. Furthermore they stated that leaders are better off empowering individuals with high autonomy orientation. Hence our proposed hypothesis is:

\section{H4: Job autonomy moderates positively between employee training and customer satisfaction}

\section{Employee Performance as mediator:}

According to Wibowo (2010), performance of employee is defined as the way employee completes the tasks assigned to him on the basis of his personal experience and qualification. Konopaske and Matteson (2005) deduced from their study that performance is an aspect of ability, opportunity and motivation to do something viable for themselves and the organization. According to Rivai (2004) performance is defined as the success of a person both qualitatively and quantitatively in a certain period of time in accordance with predetermined tasks standards. Zufri, Yunus and Ibrahim (2018) depicted employee performance as mediator between compensation, motivation and work place environment and their effect on organizational performance. From the results it was concluded that employee performance positively mediates among the relationships of compensation, motivation and work place environment on organizational performance. As in retail industry and other service industry organizational performance is based on the level of satisfaction of customers. An organization is said to perform well when its customers are satisfied and that satisfaction of customers is achieved if employees perform well and fulfill the customer demands in a timely and well manner.

Tukunimulongo (2016) studied the impact of on-the-job training on performance of employees in Kenya considering a case study of Mumias Sugar Company Limited. From the results it was concluded that performance of employees enhance due to job training. Same is the case with 
Global Journal of Human Resource Management

Vol.8, No.2, pp.33-57, June 2020

Published by ECRTD-UK

Print ISSN: 2053-5686(Print), Online ISSN: 2053-5694(Online)

service and retail sector, if employees are offered training programs on their job so their performance will enhance and they will satisfy the needs of customers excellently and ultimately customer satisfaction will enhance. According to Sultan et al. (2012), employees who are given training on their job are said to be perform well in contrast to the employees who are not offered training programs. Hays and Hill (1999) concluded from their study that it's hard to achieve customer satisfaction in services sector rather than manufacturing which is due to face to face interaction between customer and employee. They stated that employee performance is important aspect of service industry which ultimately results in satisfaction of customers.

Taba, M.I. (2018) studied worker performance and organizational commitment on the association between reward system and employee work performance and concluded that work performance and organizational commitments mediates positively between extrinsic and intrinsic reward system and work satisfaction. Imran et al. (2016), studied employee creativity as a mediating variable on the relationship between knowledge processes and company performance. From the results of his study it came to know that employee creativity (performance) partially mediates on the relationship between knowledge processes and company performance.

Alkhamis, Faisal (2018) studied the mediating role of employee job performance on the relationship between open book management dimensions and customer satisfaction. Open book management was measured by four dimensions i.e. employee empowerment, employee training, information sharing and employee participation. A sample of 500 both employees and managers was collected from 10 industrial firms. The results showed employee job performance positively mediates between open book management dimensions (employee empowerment, employee training, information sharing and employee participation) and customer satisfaction. Hence our proposed hypothesis is:

\section{H5: Employee Performance mediates positively between employee training and customer satisfaction}

\section{RESEARCH METHODOLOGY}

Research methodology is based on purpose of study. Research methodology is the specific procedure or technique used to recognize, select, process, and analyse information about a topic. The methodology section allows critically evaluating a study's overall validity and reliability as it answers two principal questions that how the data was collected and how the analysis has been done.

\section{The Research Design}

Remenyi, Williams, Money \& Swartz (1998), contends in his research that a researcher needs to do inside and out investigation and consider already on "What to research?" and "How to research?" The key point of all researchers is to increase the value of the current knowledge. There are two principle research design streams of directing research in particular "Qualitative research design and Quantitative research design" (Punch, 2013). In the current study Quantitative research 
Global Journal of Human Resource Management

Vol.8, No.2, pp.33-57, June 2020

Published by ECRTD-UK

Print ISSN: 2053-5686(Print), Online ISSN: 2053-5694(Online)

design has been utilized to see the relationships of variables among each other by distribution of structured questionnaires.

\section{Type of Study}

It is a causal study that recognized definite cause and effect relationships among different variables included in the model. Causal study is also called explanatory research. Due to this reason explanatory research is conducted to investigate the cause and effect of the variables on each other. This study aims to understand phenomena by discovering and measuring causal relations among studied variables.

In this study the cross-sectional study has been adopted and the data was collected just once over a period of few weeks. Cross-sectional research depends on examining and gathering data and information just once (Ruspini, 2002). The advantage of cross sectional study is that results and discoveries about the study can be generated from the collected data in a less time while studying the whole age, education, experience groups.

\section{Study Setting}

This study was conducted as a field study and the participants were asked to fill the questionnaires in their natural work environment. The respondents took part willingly and no incentive was given.

\section{Time Horizon}

The complete duration of this study is six months i.e. From February 2020 to June 2020. And the data is collected from the employees of targeted population from April, 2020 to May, 2020.

\section{Population}

Saunders et al. (2007) defined population as the full set of cases from which a sample is taken. The target population of this study was employees of retail sector of Rawalpindi and Islamabad cities, Pakistan.

\section{Sampling technique}

The non-probability sampling technique i.e. convenient sampling technique was used and those employees who were suitable for this study were approached for their well thought participation. Permission of organizations was obtained before administering questionnaires. After permission letter submitted to each of the organizations management authorities, the questionnaires were distributed through reporting the purpose of the study to each and every participant. Ethical standards were followed in assembling the data like the purpose of the study and anonymity were guaranteed to all participants.

\section{Sample Size}

Based on the sample size standard for individual researchers, given by Roscoe (1975) as cited by Sekaran (2003), the rule of thumb for sample size is that sample size will be larger than 30 and smaller than 500 as suitable size for most research i.e. (minimum sample size $n=30$ shall be adopted). Hence, considering the criteria, questionnaires were distributed to 365 employees of retail sectors. While the response rate was $65 \%$ i.e. 224 valid responses were considered for the study. 
Global Journal of Human Resource Management

Vol.8, No.2, pp.33-57, June 2020

Published by ECRTD-UK

Print ISSN: 2053-5686(Print), Online ISSN: 2053-5694(Online)

\section{Data Collection Techniques}

A structured and adopted questionnaire was used for the collection of data. The questionnaire is a trusted technique because all the responses can be recorded and time management for respondents is no issue. It is a faster method to conduct the survey. Confidentiality can be ensured as well. An introductory note to familiarize the respondents with the topic and other details of the study were integrated in the start of the questionnaire. It provided information as to why this academic research is being conducted and the secrecy of the information provided will be maintained.

\section{Scales and Measure}

5 point Likert scale questionnaires for each individual variable were adopted. This scale ranges from "Strongly agree" to "Strongly disagree" with $1=$ Strongly Disagree, $2=$ Disagree, $3=$ Uncertain, 4= Agree and 5= Strongly Agree.

\section{Employee Training}

Employee training was measured by 10 items adopted from the study of (Aziz, A) (2015). Example of items include "I can lists down all the important things emphasized in this training", "My personal competencies have improved after attending this training”.

\section{Customer Satisfaction}

Customer satisfaction was measured by 03 items adopted from the study of (Lai, L. Tung) (2005). Example of items include "My choice to purchase this service was a wise one", "I think that I did the right thing when I purchased this service", "This facility is exactly what is needed for this service".

\section{Employee Performance}

Employee Performance was measured by 05 items adopted from the study of (Ching et al.) (2016). Example of items include "My performance is better than that of my colleagues with similar qualifications", "I am satisfied with my performance at work place", "I have good knowledge of my company's products, services and insurance policy”.

\section{Job Autonomy}

Job Autonomy was measured by 09 items developed by Breaugh (1985). Example of items include "I am allowed to decide how to go about getting my job done", "I am free to choose the method(s) to use in carrying out my work", "My job is such that I can decide when to do particular work activities",

\section{Data Analysis Techniques}

When data collection was done, statistical tools were utilized to analyze the collected data. The data collected using survey was entered in to SPSS program. SPSS stands for "Statistical Package for the Social Sciences". The analysis of proposed hypothetical model was done by retrieving the scores from the recorded data in questionnaires. After the collection of data through questionnaires, it was punched into SPSS. Different tests like reliability, correlation and regression analysis are conducted on this hypothetical model. 
Global Journal of Human Resource Management

Vol.8, No.2, pp.33-57, June 2020

Published by ECRTD-UK

Print ISSN: 2053-5686(Print), Online ISSN: 2053-5694(Online)

\section{RESULTS}

\section{Age}

The age was distrusted among the intervals of 20-25, 26-30, 31-35, 36-40, 41-45 and 51 or above. There were 35 respondents among the interval of 20-25 which is $15.62 \%$ of the total. Similarly 43 respondents were from 26-30 interval which contributes to $19.2 \%$ to the total. 28 respondents were included in the range of $31-35$ which is $12.5 \%$ of the total. 35 respondents were in the age between $36-40$ comprising $15.62 \%$ of the total. A total of 30 respondents were present among the interval of $41-45$ which is $13.4 \%$ of the total. 35 respondents were the age between the intervals of $46-50$ which is $15.62 \%$ of the total. 18 respondents were the age more than 50 comprising $8.04 \%$ of the total sample population. The details are showed in the table-4.1 as following;

Table 4.1

\begin{tabular}{llll}
\hline & Frequency & Percent & Cumulative Percent \\
\hline $20-25$ & 35 & 15.62 & 15.62 \\
$26-30$ & 43 & 19.2 & 34.82 \\
$31-35$ & 28 & 12.5 & 47.32 \\
$36-40$ & 35 & 15.62 & 62.94 \\
$41-45$ & 30 & 13.4 & 76.34 \\
$46-50$ & 35 & 15.62 & 91.96 \\
51 or above & 18 & 8.04 & 100.0 \\
Total & 224 & 100.0 & \\
\hline
\end{tabular}

The maximum data was collected from 26-30 age intervals i.e. 43 while the minimum data was obtained from age interval of 51 or above i.e. 18 .

\section{Gender:}

The data was collected from 224 personals which comprised of 137 males (61.2\% of total) and 87 females $(38.8 \%$ of total).

\section{Table 4.2}

\section{Gender}

\begin{tabular}{llll}
\hline & Frequency & Percent & Cumulative Percent \\
\hline Male & 137 & 61.2 & 61.2 \\
Female & 87 & 38.8 & 100.0 \\
Total & 224 & 100.0 & \\
\hline
\end{tabular}

\section{Education:}

In this category, $31.3 \%$ were bachelors or below; masters were $48.7 \%$; M.S/M.PHIL were $15.6 \%$; and others were $4.4 \%$. 
Global Journal of Human Resource Management

Vol.8, No.2, pp.33-57, June 2020

Published by ECRTD-UK

Print ISSN: 2053-5686(Print), Online ISSN: 2053-5694(Online)

\begin{tabular}{llll}
\multicolumn{1}{c}{ Table 4.3 } & Education & \\
\hline & Frequency & Percent & Cumulative Percent \\
\hline Bachelor or below & 70 & 31.3 & 31.3 \\
Masters & 109 & 48.7 & 80.0 \\
MS/MPHIL & 35 & 15.6 & 95.6 \\
Others & 10 & 4.4 & 100.0 \\
Total & 224 & 100.0 & \\
\hline
\end{tabular}

The maximum data was obtained from Masters category i.e. 109 while the minimum was from others i.e. 10.

\section{Experience:}

In experience category less than 5 years was $31.3 \%, 6-10$ years were $29.9 \%, 11-15$ years were $20.1 \%, 16$ or above were $18.7 \%$.

Table 4.4

Experience

\begin{tabular}{llll}
\hline & Frequency & Percent & Cumulative Percent \\
\hline Less than 05 years & 70 & 31.3 & 31.3 \\
6-10 years & 67 & 29.9 & 61.2 \\
11-15 years & 45 & 20.1 & 81.3 \\
16 years or above & 42 & 18.7 & 100.0 \\
Total & 70 & 100.0 & \\
\hline
\end{tabular}

\section{Reliability Analysis:}

The Cronbach's Alpha coefficients of all variables under study were obtained. The minimum threshold of Cronbach's Alpha is 0.70 (Nunnally and Bernstein, 1994). Table 4.5 shows that the Cronbach's Alpha for all variables were greater than 0.70 which means that the scale is highly reliable.

\section{Table 4.5 Reliability Analysis}

\begin{tabular}{lll} 
Variable & No of items & $\boldsymbol{\alpha}$ \\
Employee Training & 10 & 0.824 \\
Customer Satisfaction & 03 & 0.796 \\
Employee Performance & 05 & 0.775 \\
Job Autonomy & 09 & 0.702 \\
\hline
\end{tabular}

\section{Correlation Analysis:}

The results of the statistical test of correlation are presented in the table-4.6. Hence, the correlation is described individually as under:

- $\quad$ Correlation analysis showed that Employee training (IV) is positively correlated with Customer Satisfaction (DV) i.e. $\mathrm{r}=.750^{* *}$ which provides support to the hypothesis that employee training has a positive impact on customer satisfaction. Similarly Table 4.6 showed that Employee training (IV) is positively associated with Employee Performance (Mediator) and Job Autonomy (Moderator) i.e. $\mathrm{r}=.670^{* *}$ and $\mathrm{r}=.721^{* *}$ respectively. 
Global Journal of Human Resource Management

Vol.8, No.2, pp.33-57, June 2020

Published by ECRTD-UK

Print ISSN: 2053-5686(Print), Online ISSN: 2053-5694(Online)

- $\quad$ Similarly Customer satisfaction is positively related with Employee Performance and Job Autonomy with correlation coefficient of .648** and $.542 * *$ respectively.

- $\quad$ Similarly Employee Performance and Job Autonomy are positively correlated with each other with correlation coefficient $(r)=.611^{* *}$

Table 4.6 Correlation Analysis

\begin{tabular}{lllllll}
\hline Predictors & Mean & $\begin{array}{l}\text { Standard } \\
\text { Deviation }\end{array}$ & 1 & 2 & 3 & 4
\end{tabular}

$\begin{aligned} & \text { Employee } \\ & \text { Training }\end{aligned}$
$\begin{aligned} & \text { Customer } \\ & \text { Satisfaction }\end{aligned}$
$\begin{aligned} & \text { Employee } \\ & \text { Performance }\end{aligned}$
Job Autonomy

Employee Training and Customer satisfaction:

Table 4.7 Results of Linear Regression Analysis (Employee training and Customer Satisfaction)

Predictors

Customer Satisfaction 
Global Journal of Human Resource Management

Vol.8, No.2, pp.33-57, June 2020

Published by ECRTD-UK

Print ISSN: 2053-5686(Print), Online ISSN: 2053-5694(Online)

regression analysis. Beta value, i.e., $(\beta=0.979 * * *)$, revealed that there was a positive association between employee training and customer satisfaction and one unit increase in employee training will cause $97.9 \%$ increase in the customer satisfaction.

From the table 4.7 it is inferred that variation in Customer satisfaction (DV) explained by employee training (IV) is $56.3 \%\left(\mathrm{R}^{2}=.563\right)$.

\section{Employee training and Employee performance:}

Table 4.8 Results of Linear Regression Analysis (Employee training and Employee Performance)

Predictors

\section{Employee Performance}

\begin{tabular}{lccc} 
& $\mathbf{B}$ & $\mathbf{R}^{2}$ & sig \\
1. Employee Training & $0.921 * * *$ & $.449 * * *$ & .000 \\
\hline $\begin{array}{l}\mathrm{IV}=\text { Employee training, } \\
* * * \mathrm{p} \leq .001 * * *\end{array}$ & Employee Performance $(\mathrm{MV}), * \mathrm{p} \leq .05^{*}, * * \mathrm{p} \leq .01 * *$,
\end{tabular}

The results from table 4.8 showed that the second hypothesis, i.e. Employee training has a positive impact on employee performance has been supported as showed by the regression analysis. Beta value, i.e., $(\beta=0.921 * * *)$, revealed that there was a positive association between employee training and employee performance and one unit increase in employee training will cause an increase of $92.1 \%$ in the employee performance.

From the table 4.8 it is inferred that variation in Employee performance (MV) explained by employee training (IV) is $44.9 \%\left(\mathrm{R}^{2}=.449\right)$.

\section{Employee Performance and Customer Satisfaction:} Table 4.9 Results of Linear Regression Analysis (Employee Performance and Customer Satisfaction) Predictors

\begin{tabular}{llll} 
& $\mathbf{B}$ & $\mathbf{R}^{2}$ & Sig \\
1. Employee Performance & $0.616^{* * *}$ & $.420 * * *$ & .000 \\
\hline $\begin{array}{l}\mathrm{MV}=\text { Employee Performance, } \\
* * * \mathrm{p} \leq .001 * * *\end{array}$ & $\mathrm{DV}=$ Customer & Satisfaction, $* \mathrm{p} \leq .05^{*}, * * \mathrm{p} \leq .01^{* *}$,
\end{tabular}

The results from table 4.9 showed that the third hypothesis, i.e. Employee Performance (mediator) has a positive impact on Customer Satisfaction (DV) has been supported as showed by the regression analysis. Beta value, i.e., $\left(\beta=0.616^{* * *}\right)$, revealed that there was a positive association between employee performance and customer satisfaction and one unit increase in employee performance will cause an increase of $61.6 \%$ in the customer satisfaction. 
Global Journal of Human Resource Management

Vol.8, No.2, pp.33-57, June 2020

Published by ECRTD-UK

Print ISSN: 2053-5686(Print), Online ISSN: 2053-5694(Online)

From the table 4.9 it is inferred that variation in Customer satisfaction (DV) explained by employee performance (mediator) is $42 \%\left(\mathrm{R}^{2}=.420\right)$.

Moderation Analysis:

Table 4.10 Job Autonomy as moderator between Employee Training and Customer Satisfaction:

Step 1

Control variable (Gender)

\section{Team Performance \\ Beta $\square R^{2}$}

Step 2

Employee Training

.153

Job Autonomy $\quad .197 * * \quad .574 * * *$

Step 3

ETXJA $\quad .386 * * \quad .599 * * *$

$* \mathrm{p} \leq .05 *, * * \mathrm{p} \leq .01 * *, * * * \mathrm{p} \leq .001 * * *$

Table 4.10 provides the results for the moderation analysis. The hypothesis four which is job autonomy moderates positively the association between employee training and customer satisfaction. The hypothesis is supported by the results of the following research for interaction term with $\beta=.386^{* *} ; \Delta \mathrm{R}^{2}=.599^{* * *}$ and $\mathrm{P}$ value $=0.000$. The stated results revealed that job autonomy positively moderates the association between employee training and customer satisfaction.

Mediation Analysis:

Employee Performance as mediator between Employee Training and Customer Satisfaction

This study used employee performance as mediator between employee training and customer satisfaction. Preacher and Hayes method of mediation analysis was used to see the direct effect of employee training on customer satisfaction by controlling the mediator, indirect effect of Employee training on Customer satisfaction by introducing Employee Performance as mediator, and the total effect of Employee training on customer satisfaction.

The indirect impact of employee training on employee performance (indicated by path a) and that of employee performance on customer satisfaction (indicated by path b) were highly significant with beta values of $.921^{* * *}$ and $.251^{* *}$ respectively. Similarly controlling for the mediator i.e. Employee performance, Employee training was still a significant predictor of customer satisfaction with $($ Beta $=.747 * * *)$ as indicated by path c' 


\section{MEDIATION DIAGRAM}

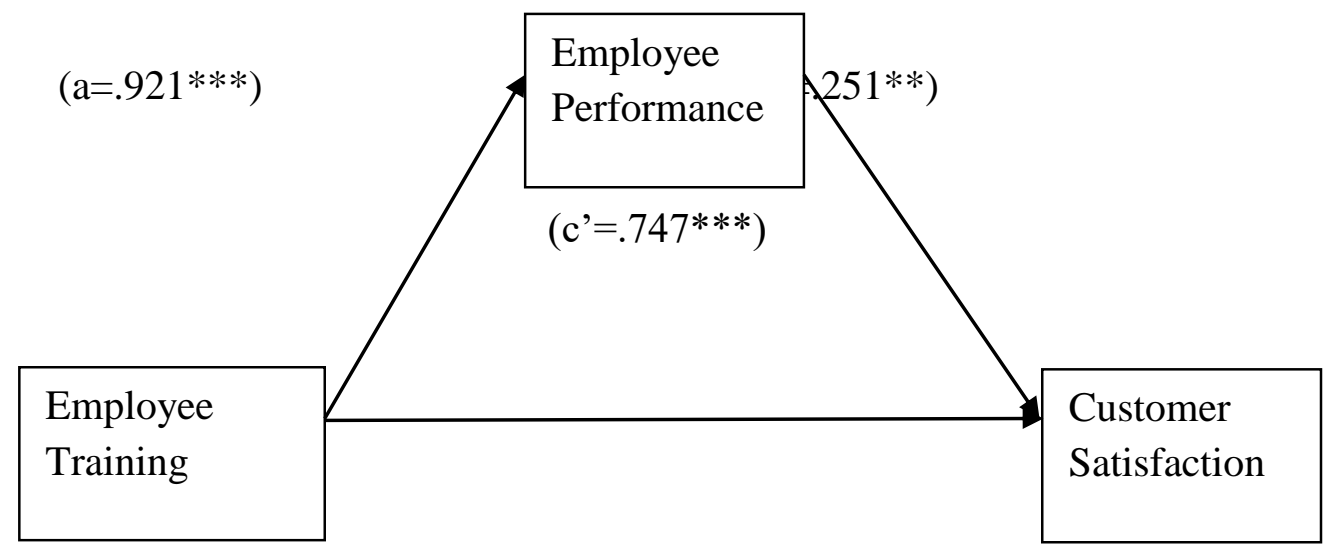

Path $\mathrm{a}=.921 * * *$

Path $b=.251 * *$

Path $\mathrm{c}^{\prime}=.747 * * *$

Indirect effect $=$ Path $\mathrm{a} *$ Path $\mathrm{b}$

$$
=.921 x .251
$$$$
=.231
$$

Direct effect $=.747 * * *$

Total effect $(c)=$ Direct effect + Indirect effect

$$
\begin{aligned}
& =.747+.231 \\
& =.978
\end{aligned}
$$

The $5^{\text {th }}$ Hypothesis (H5) which is employee performance positively mediates between employee training and customer satisfaction. The hypothesis is supported by the results which showed that, controlling for the mediator Employee Performance, Employee training scores were still a significant predictor of customer satisfaction scores, Beta $=0.747 * * *$, the finding indicates partial mediation as the effect of employee training on customer satisfaction reduces to (.231) when employee performance was used as a mediator. To see that whether indirect effect is significant or non-significant, we need to analyze the bootstrap interval i-e Boot LLCI and Boot ULCI, if zero is included in the interval then the indirect effect is said to be non-significant otherwise significant. The results revealed that (Boot LLCI $=.770$ and Boot ULCI=1.19) which means that the interval is $[.770,1.19]$. As this interval doesn't include zero so the indirect effect is significant and employee performance exists as a mediator between employee training and customer satisfaction. 
Global Journal of Human Resource Management

Vol.8, No.2, pp.33-57, June 2020

Published by ECRTD-UK

Print ISSN: 2053-5686(Print), Online ISSN: 2053-5694(Online)

Testing for Mediation: Employee Performance (EP) as Mediator between ET and CS

Table 4.11

\begin{tabular}{llllllll}
\hline Predictor & $\begin{array}{l}\text { Effect of } \\
\text { IV on M }\end{array}$ & $\begin{array}{llll}\text { Effect of } \\
\text { M on DV }\end{array}$ & $\begin{array}{l}\text { Direct } \\
\text { Effect }\end{array}$ & $\begin{array}{l}\text { Indirect } \\
\text { Effect of } \\
\text { IV on DV }\end{array}$ & $\begin{array}{l}\text { Total } \\
\text { Effect }\end{array}$ & $\begin{array}{l}\text { Bootstrapping results for } \\
\text { indirect effects }\end{array}$ \\
\hline & & & & & & LL & UL \\
& & & & & & $95 \%$ & $95 \%$ \\
EI & CI \\
Training & $0.921^{* * * *}$ & $0.251^{* *}$ & $\begin{array}{llll}0.747^{* *} \\
*\end{array}$ & & $0.9785^{* *}$ & 0.770 & 1.19 \\
\hline
\end{tabular}

$I V=$ Independent variable, $D V=$ dependent variable, $M=$ mediator, $L L=$ lower limit, UL=upper limit, $C I=$ confidence interval $n=70 ; * p<.05$, ** $p<.01$, ***p<.001;

\section{DISCUSSION AND CONCLUSION}

\section{Discussion:}

This investigation is an effort to empirically scrutinize the impact of employee training on customer satisfaction by utilizing the effect of employee performance as mediator and job autonomy as moderator. The results from this study are consistent with past empirical studies. In this investigation besides direct effect employee training on customer satisfaction, mediation effects have also been deeply examined. Moreover, the mediating effect of employee performance on the association between employee training and customer satisfaction were also empirically tested and found highly significant. The research results have evidently shown that employee performance positively mediates between employee training and customer satisfaction. Similarly in this study job autonomy was utilized as moderator between employee training and customer satisfaction. From the results it was clear that job autonomy moderates positively between employee training and customer satisfaction.

\section{Employee training and customer satisfaction:}

From (Table 4.7) of results section, it is clear that employee training positively impact the customer satisfaction. The customer satisfaction enhances as the employee training enhances. So it is necessary to initiate training of employees in the organizations in order to enhance customer satisfaction. Hence our proposed hypothesis is accepted.

H1: Employee training has a positive impact on customer satisfaction (Accepted)

\section{Employee training and employee performance:}

The results from table 4.8 show that employee training has a positive impact on employee performance. The performance of employee boosts as the employee training enhances. That's why training must be introduced in the organizations so in order to ameliorate employee performance. Hence our proposed hypothesis is accepted.

H2: Employee training has a positive impact on employee performance 
Global Journal of Human Resource Management

Vol.8, No.2, pp.33-57, June 2020

Published by ECRTD-UK

Print ISSN: 2053-5686(Print), Online ISSN: 2053-5694(Online)

\section{Employee performance and customer satisfaction:}

From table 4.9 of results section, it is clear that employee performance has a positive impact on customer satisfaction. The customer satisfaction increases as the employee performance increases. Due to this reason it is beneficial for the organization to take every possible step in order to enhance employee performance which will enhance customer satisfaction. And ultimate profit will be for organization. Hence our proposed hypothesis is accepted.

\section{H3: Employee performance has a positive impact on customer satisfaction}

\section{Job autonomy as moderator:}

From regression analysis (table 4.10) it was clear that job autonomy positively moderates between employee training and customer satisfaction. And as training of employees enhance so job autonomy will enhance and ultimately customer satisfaction enhances. That's it is necessary for organizations to enhance training of employees which will enhance job autonomy of employees and employees will work independently, which will result in increase in level of customer satisfaction. Hence our proposed hypothesis is accepted.

H4: Job autonomy moderates positively between employee training and customer satisfaction

\section{Employee Performance as mediator:}

In this study employee performance was used as mediator on the association between employee training and customer satisfaction. The results from mediation analysis (table 4.11) show that employee performance positively mediates between employee training and customer satisfaction. Hence our proposed hypothesis is accepted.

H5: Employee Performance mediates positively between employee training and customer satisfaction

\section{Conclusion:}

In this study an effort has been made to observe the impact of Employee training on customer satisfaction. It can be well concluded that employee training positively and significantly impact customer satisfaction. Furthermore, satisfaction of the customers can be enhanced by initiating training of employee inside the organization. The results suggest that there is a noteworthy positive link of employee training with customer satisfaction. Similarly employee performance positively mediates between employee training and customer satisfaction. By initiating training of employees in the organization, the performance of employee enhances, which will boost up the customer satisfaction. Similarly job autonomy positively moderates between employee training and customer satisfaction. By introducing training of employees in organization enhances job autonomy of employees which will enhance customer satisfaction.

\section{Managerial Implications}

- $\quad$ Managers should introduce training of employees in their organizations as it will help employees to perform their jobs autonomously due to which the customers will be satisfied.

- Managers shall arrange training sessions for employees because it will enhance the performance of employee and ultimately profit will be for the organization 
Global Journal of Human Resource Management

Vol.8, No.2, pp.33-57, June 2020

Published by ECRTD-UK

Print ISSN: 2053-5686(Print), Online ISSN: 2053-5694(Online)

- $\quad$ Managers should train the employees in such a way that they act as autonomous bodies and work independently due to which customers will be satisfied.

\section{Limitations:}

The following are the limitations of this study:

- $\quad$ The sample size was taken from two cities of Pakistan i.e. Islamabad and Rawalpindi. So our conclusions were restrained from external setup. Researchers can recreate this idea in different nations in order to generalize the results of this study.

- $\quad$ The size of sample selected was low therefore researchers can carry out this study with large sample size so as to generalize this study.

\section{REFRENCES:}

van Dolen, W., de Ruyter, K., \& Lemmink, J. (2004). An empirical assessment of the influence of customer emotions and contact employee performance on encounter and relationship satisfaction. Journal of Business Research, 57(4), 437-444. https://doi.org/10.1016/S01482963(02)00277-1

Shafiq, S. (2018). THE EFFECT OF TRAINING AND DEVELOPMENT ON EMPLOYEE PERFORMANCE IN PRIVATE COMPANY, MALAYSIA Impact of CEO Gender on Employee Turnover and Returns Per Employee View project. March, 41-56. https://doi.org/10.13140/RG.2.2.33047.68005

Ng, K. Y., Ang, S., \& Chan, K. Y. (2008). Personality and Leader Effectiveness: A Moderated Mediation Model of Leadership Self-Efficacy, Job Demands, and Job Autonomy. Journal of Applied Psychology, 93(4), 733-743. https://doi.org/10.1037/0021-9010.93.4.733

Vehviläinen, A., Lasserre, J., Ljung, M., \& Paczkowski, M. (2004). Productivity gains. In Tissue World (Issue DEC./JAN., pp. 37-38).

Konečnik Ruzzier, M., Ruzzier, M., \& Hisrich, R. (2014). Value, satisfaction and customer loyalty. Marketing for Entrepreneurs and SMEs, November, 21-36. https://doi.org/10.4337/9781781955970.00008

Altonji, J. G., \& Spletzer, J. R. (1991). Worker Characteristics, Job Characteristics, and the Receipt of On-the-Job Training. Industrial and Labor Relations Review, 45(1), 58. https://doi.org/10.2307/2524702

Lee, Y. C., Wang, Y. C., Lu, S. C., Hsieh, Y. F., Chien, C. H., Tsai, S. B., \& Dong, W. (2016). An empirical research on customer satisfaction study: a consideration of different levels of performance. SpringerPlus, 5(1). https://doi.org/10.1186/s40064-016-3208-Z

Awang, A., Ibrahim, I. I., Md Nor, M. N., Mohd Razali, M. F., Mat Arof, Z., \& Abdul Rahman, A. R. (2015). Academic Factors and Turnover Intention: Impact of Organization Factors. Higher Education Studies, 5(3). https://doi.org/10.5539/hes.v5n3p24

Hughey, A. W., \& Mussnug, K. J. (1997). Designing effective employee training programmes. Training for Quality, 5(2), 52-57. https://doi.org/10.1108/09684879710167638

Gottman, J. M., Coan, J., Carrere, S., Swanson, C., Gottman, J. M., Coan, J., Carrere, S., \& Swanson, C. (1998). Predicting Marital Happiness and Stability from Newlywed Interactions Published by: National Council on Family Relations Predicting Marital 
Global Journal of Human Resource Management

Vol.8, No.2, pp.33-57, June 2020

Published by ECRTD-UK

Print ISSN: 2053-5686(Print), Online ISSN: 2053-5694(Online)

Happiness and Stability from Newlywed Interactions. Journal of Marriage and Family, 60(1), 5-22. https://doi.org/10.1002/job

Vyasulu, V. (1976). Towards an Alternate Technology. India International Centre Quarterly, 3(1), 77-99. http://www.jstor.org/stable/23001865

Yunus, M., Ibrahim, M., Kuala, U. S., Aceh-indonesia, B., Kuala, U. S., \& Aceh-indonesia, B. (2018). the Role of Employee Performance As a Mediation Variable in the Effect of Compensation, Motivation, and the Environment of the Workplace on. European Journal of Research and Reflection in Management Sciences, 6(4), 75-83.

Haar, J. M., \& Spell, C. S. (2009). How does distributive justice affect work attitudes? The moderating effects of autonomy. The International Journal of Human Resource Management, 20(8), 1827-1842. https://doi.org/10.1080/09585190903087248

Hallowell, R. (1996). The relationships of customer satisfaction, customer loyalty, and profitability: An empirical study. International Journal of Service Industry Management, 7(4), 27-42. https://doi.org/10.1108/09564239610129931

Abbasi, A. S., \& Alvi, A. K. (2013). Impact of Employee Characteristics and Their Performance on Customer Satisfaction. Sci.Int.(Lahore), 25(2), 387-394. http://www.ciitlahore.edu.pk/Papers/Abstracts/539-8588355598103049558.pdf

Chaichi, K. (2012). Impact of staff training on customer satisfaction in travel agencies in Klang valley Malaysia. European Journal of Social Sciences, 29(2), 270-282.

Netemeyer, R. G., Maxham, J. G., \& Lichtenstein, D. R. (2010). Store Manager Performance and Satisfaction: Effects on Store Employee Performance and Satisfaction, Store Customer Satisfaction, and Store Customer Spending Growth. Journal of Applied Psychology, 95(3), 530-545. https://doi.org/10.1037/a0017630

Hasan, S. A., Subhani, M. I., \& Rehman, A. (2011). Relationship between various employee performance recognition techniques and customer satisfaction: Evidence from the restaurant industry of Pakistan. European Journal of Social Sciences, 26(3), 318-322.

Zhou, Q., Li, Q., \& Gong, S. (2019). How Job Autonomy promotes employee's sustainable development? A moderated mediation model. Sustainability (Switzerland), 11(22), 1-14. https://doi.org/10.3390/su11226445

Rust, R. T., \& Zahorik, A. J. (1993). Customer satisfaction, customer retention, and market share. In Journal of Retailing (Vol. 69, Issue 2, pp. 193-215). https://doi.org/10.1016/00224359(93)90003-2

Bearden, W. O., \& Teel, J. E. (1983). Selected Determinants of Consumer Satisfaction and Complaint Reports. Journal of Marketing Research, 20(1), 21. https://doi.org/10.2307/3151408

Saragih, S. (2011). The Effects of Job Autonomy on Work Outcomes: Self Efficacy as an Intervening Variable. International Research Journal of Business Studies, 4(3), 203-215. https://doi.org/10.21632/irjbs.4.3.203-215

Abogsesa, A. S., \& Kaushik, G. (2018). Impact of Training and Development on Employee Performance. International Journal of Civic Engagement and Social Change, 4(3), 53-68. https://doi.org/10.4018/ijcesc.2017070104

Volmer, J., Spurk, D., \& Niessen, C. (2012). Leader-member exchange (LMX), job autonomy, and creative work involvement. Leadership Quarterly, 23(3), 456-465. https://doi.org/10.1016/j.leaqua.2011.10.005 
Global Journal of Human Resource Management

Vol.8, No.2, pp.33-57, June 2020 Published by ECRTD-UK

Print ISSN: 2053-5686(Print), Online ISSN: 2053-5694(Online)

Jafri, M. H. (2018). Moderating Role of Job Autonomy and Supervisor Support in Trait Emotional Intelligence and Employee Creativity Relationship. Vision, 22(3), 253-263. https://doi.org/10.1177/0972262918785960

Hayes, A. (2013). Integrating Mediation and Moderation Analysis: fundamentals using PROCESS. In Introduction to Mediation, Moderation and Conditional Process Analysis. https://doi.org/978-1-60918-230-4

Iqbal, N., Ahmad, N., Haider, Z., Batool, Y., \& ul-ain, Q. (2013). Impact of performance appraisal on employee's performance involving the Moderating Role of Motivation. Oman Chapter of Arabian Journal of Business and Management Review, 3(1), 37-56. https://doi.org/10.12816/0002354

Shigenobu, K., \& Ikeda, M. (2009). Care for the patients with frontotemporal lobar degeneration. Brain and Nerve, 61(11), 1337-1342.

(INFLUENCE OF TRANSFORMATIONAL LEADERSHIP ON ORGANIZATIONAL PERFORMANCE OF COMMERCIAL BANKS IN KENYA (Leadership and Governance ) JOMO KENYATTA UNIVERSITY OF, 2017)

Lai, T. L. (2004). Service quality and perceived value's impact on satisfaction, intention and usage of short message service (SMS). Information Systems Frontiers, 6(4), 353-368. https://doi.org/10.1023/B:ISFI.0000046377.32617.3d

Aziz, S. F. A. (2015). Developing general training effectiveness scale for the Malaysian workplace learning. Mediterranean Journal of Social Sciences, 6(4S1), 47-56. https://doi.org/10.5901/mjss.2015.v6n4s1p47

Russell, M. (2017). Nighthawks Open Institutional Repository The Relationships among Autonomy, Job Satisfaction and Motivation. https://digitalcommons.northgeorgia.edu/honors_theses 
Global Journal of Human Resource Management

Vol.8, No.2, pp.33-57, June 2020

Published by ECRTD-UK

Print ISSN: 2053-5686(Print), Online ISSN: 2053-5694(Online)

\section{Questionnaires}

(Please tick the appropriate checkbox below)

Section 1: Demographic Questions

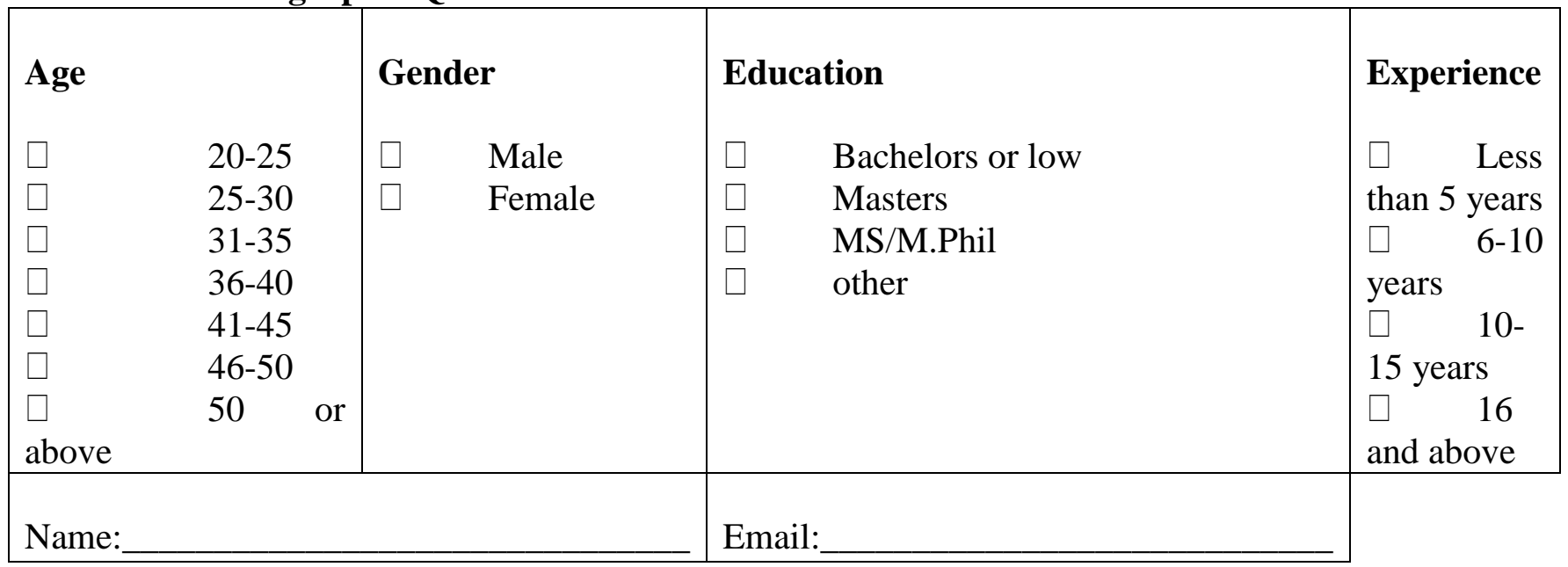

\section{Section 2}

\begin{tabular}{|l|l|l|l|l|l|}
\hline Employee Training & $\begin{array}{l}\text { Strongly } \\
\text { Disagree }\end{array}$ & Disagree & Uncertain & Agree & $\begin{array}{l}\text { Strongly } \\
\text { Agree }\end{array}$ \\
\hline $\begin{array}{l}1 . \quad \text { I can lists down all the important } \\
\text { things emphasized in this training }\end{array}$ & & & & \\
\hline $\begin{array}{l}\text { 2. I know how to solve certain job } \\
\text { problems using the skills taught in this } \\
\text { training }\end{array}$ & & & & \\
\hline $\begin{array}{l}3 . \quad \text { I know how to work more efficient } \\
\text { using the knowledge learned in this } \\
\text { training. }\end{array}$ & & & & \\
\hline $\begin{array}{l}\text { 4. I have the capability to perform the } \\
\text { skills taught in this training. }\end{array}$ & & & & \\
\hline $\begin{array}{l}5 . \quad \text { My personal competencies have } \\
\text { improved after attending this training. }\end{array}$ & & & & \\
\hline $\begin{array}{l}\text { 6. I am being more professional in } \\
\text { certain tasks after attending this training. }\end{array}$ & & & & \\
\hline $\begin{array}{l}7 . \quad \text { My job performance has improved } \\
\text { as a result of applying the skills } \\
\text { emphasized in this training. }\end{array}$ & & & & & \\
\hline $\begin{array}{l}8 . \\
\text { has improved due to the skills that Ilearned } \\
\text { and used in this training either directly or } \\
\text { indirectly }\end{array}$ & & & & & \\
\hline
\end{tabular}


Global Journal of Human Resource Management

Vol.8, No.2, pp.33-57, June 2020

Published by ECRTD-UK

Print ISSN: 2053-5686(Print), Online ISSN: 2053-5694(Online)

\begin{tabular}{|c|c|c|c|c|c|}
\hline \multicolumn{6}{|l|}{$\begin{array}{l}9 . \text { What I have learned in this training } \\
\text { has improved my job performance and } \\
\text { subsequently my organizational } \\
\text { nerformance }\end{array}$} \\
\hline $\begin{array}{l}10 . \quad \text { I have contributed to improving my } \\
\text { organization's reputation due to the } \\
\text { outcome of this training either directly or } \\
\text { indirectly. }\end{array}$ & & & & & \\
\hline Customer Satisfaction & $\begin{array}{l}\text { Strongly } \\
\text { Disagree }\end{array}$ & Disagree & Uncertain & Agree & $\begin{array}{l}\text { Strongly } \\
\text { Agree }\end{array}$ \\
\hline $\begin{array}{l}\text { 1. My choice to purchase this service } \\
\text { was a wise one. }\end{array}$ & & & & & \\
\hline $\begin{array}{l}\text { 2. I think that I did the right thing } \\
\text { when I purchased this service. }\end{array}$ & & & & & \\
\hline $\begin{array}{l}\text { 3. This facility is exactly what is } \\
\text { needed for this service. }\end{array}$ & & & & & \\
\hline Employee Performance & $\begin{array}{l}\text { Strongly } \\
\text { Disagree }\end{array}$ & Disagree & Uncertain & Agree & $\begin{array}{l}\text { Strongly } \\
\text { Agree }\end{array}$ \\
\hline $\begin{array}{l}\text { 1. My performance is better than that } \\
\text { of my colleagues with similar } \\
\text { qualifications. }\end{array}$ & & & & & \\
\hline $\begin{array}{l}\text { 2. I am satisfied with my performance } \\
\text { at work place. }\end{array}$ & & & & & \\
\hline $\begin{array}{l}\text { 3. I am committed to have continuous } \\
\text { quality improvement in my work. }\end{array}$ & & & & & \\
\hline $\begin{array}{l}\text { 4. I have good support from my } \\
\text { supervisor in handling my tasks }\end{array}$ & & & & & \\
\hline $\begin{array}{l}5 . \quad \text { I have good knowledge of my } \\
\text { company's products, services and } \\
\text { insurance policy. }\end{array}$ & & & & & \\
\hline Job Autonomy & $\begin{array}{l}\text { Strongly } \\
\text { Disagree }\end{array}$ & Disagree & Uncertain & Agree & $\begin{array}{l}\text { Strongly } \\
\text { Agree }\end{array}$ \\
\hline $\begin{array}{l}\text { 1. I am allowed to decide how to go about } \\
\text { getting my job done }\end{array}$ & & & & & \\
\hline $\begin{array}{l}\text { 2. I have control over the sequencing of } \\
\text { my work activities }\end{array}$ & & & & & \\
\hline $\begin{array}{l}\text { 3. I am able to modify what my job } \\
\text { objectives are }\end{array}$ & & & & & \\
\hline $\begin{array}{l}\text { 4. I have some control over what I am } \\
\text { supposed to accomplish }\end{array}$ & & & & & \\
\hline $\begin{array}{l}\text { 5. I am free to choose the method(s) to } \\
\text { use in carrying out my work }\end{array}$ & & & & & \\
\hline
\end{tabular}


Global Journal of Human Resource Management

Vol.8, No.2, pp.33-57, June 2020

Published by ECRTD-UK

Print ISSN: 2053-5686(Print), Online ISSN: 2053-5694(Online)

\begin{tabular}{|l|l|l|l|l|l|}
\hline $\begin{array}{l}\text { 6. My job allows me to modify the } \\
\text { normal way we are evaluated so that I can } \\
\text { emphasize some aspects of my job and } \\
\text { play down others. }\end{array}$ & & & & & \\
\hline $\begin{array}{l}\text { 7. I am able to choose the way to go about } \\
\text { my job }\end{array}$ & & & & & \\
\hline $\begin{array}{l}\text { 8. I have control over the scheduling of } \\
\text { my work. }\end{array}$ & & & & & \\
\hline $\begin{array}{l}\text { 9. My job is such that I can decide when } \\
\text { to do particular work activities. }\end{array}$ & & & & & \\
\hline
\end{tabular}

